\title{
Etiology and Management of a Mandarin Rind Disorder in California
}

\author{
J. E. Adaskaveg, Department of Plant Pathology and Microbiology, University of California, Riverside 92521; \\ H. Förster, Department of Plant Pathology, University of California, Davis 95616; and J. H. Connell, University of \\ California Cooperative Extension, Oroville 95965
}

\begin{abstract}
Adaskaveg, J. E., Förster, H., and Connell, J. H. 2010. Etiology and management of a mandarin rind disorder in California. Plant Dis. 94:1485-1490.

Recent reports of a preharvest rind disorder of Satsuma mandarin fruit resulted in severe crop losses in some growing areas of California (Butte, Fresno, Tulare, and Kern Counties). Symptoms were more frequently observed on fruit on the outer perimeter of the tree and on the exposed side of the fruit. Fungal isolations from affected fruit were inconsistent among orchard sites and growing seasons. Isolations resulted in species of Alternaria, Fusarium, Macrophomina, Ulocladium, and Cladosporium. In laboratory studies, mandarin fruit that were soaked in water for $6 \mathrm{~h}$ at 15 to $35^{\circ} \mathrm{C}$, air dried, and incubated at $20^{\circ} \mathrm{C}$ for 3 days developed lesions similar to those observed in the field. When fruit were treated with an agricultural summer spray oil or the antitranspirant di-1-p-menthene prior to water soaking, the incidence and severity of the disorder were significantly reduced. Similar results were obtained in 2 years of field trials at two sites using one to three preharvest applications with the agricultural antitranspirant or summer oil starting after fruit color break. In most trials, a single application of these treatments at 1 or 2 weeks after color break was highly effective. Fungicides were inconsistent in their efficacy, whereas trees that were physically protected from rain did not develop the disorder. These data suggest that this mandarin rind disorder is a physiological, abiotic disorder rather than a pathological problem caused by fungi and can be economically managed with water-repellant treatments.
\end{abstract}

In recent years, outbreaks of a mandarin rind disorder have caused serious crop losses in several citrus-growing counties of California from the southern to northern Central Valley (e.g., Butte, Fresno, Kern, and Tulare Counties). The damage occurred after color break in the fall, shortly following rainfall. It was most severe on Satsuma mandarin fruit but also affected other early-season mandarin cultivars such as Clementine. Symptoms initially appeared as irregular, water-soaked areas that were more frequently observed on the exposed side of the fruit on the outer perimeter of the tree. These areas developed into irregular, dark-brown, necrotic lesions that frequently covered large portions of the fruit surface. Affected fruit often rapidly decayed after harvest.

Rind disorders similar in appearance have been previously described for other citrus fruit such as Navel and Valencia orange, as well as lemon. They have been attributed to various environmental conditions, including nutritional imbalances (4), rainy periods followed by wind (12), or cold wind (12). Fawcett (10) related the

Corresponding author: J. E. Adaskaveg

E-mail: jim.adaskaveg@ucr.edu

Accepted for publication 26 August 2010.

doi:10.1094/PDIS-07-10-0484

(C) 2010 The American Phytopathological Society occurrence of rind breakdown to wet weather and low temperatures. His explanation for tissue injury and browning was the liberation of rind oil, and the occurrence of sunken rind areas was the collapse of cells just underneath the cuticle. Fawcett (10) also noted the appearance of saprophytic fungi and of fruit decay when wet weather continued to prevail. Sudden changes in relative humidity followed by high temperatures and subsequent high evapotranspiration were found to be responsible for a rind breakdown of Navel orange fruit in Spain (1). In this latter study, membrane damage and cell collapse in the flavedo and albedo were observed in necrotic lesions on the rind.

Thus, causes of preharvest rind disorders of citrus fruit can be complex. Still, there is little information on this disorder for mandarin fruit. Some pest control advisors in California suggested that infections by Alternaria spp. were responsible for the disorder. Based on this information, the citrus industry of California recently supported a label amendment for azoxystrobin and a Section 18 emergency registration for the premixture fungicide product boscalid-pyraclostrobin (Pristine) to include the control of Alternaria spp. Farm advisors and a researcher, however, noted inconsistent results using these fungicides in preharvest applications (M. Freeman, J. H. Connell, and J. E. Adaskaveg, unpublished). In preliminary fungal isolations from affected tissue, species of several fungal genera, including Alternaria and Fusarium, were obtained but isolations were not consistent, and other potential primary causes such as environmental conditions were speculated (6). The objectives of this study were to determine the cause of the recent outbreaks of mandarin rind disorder in California, evaluate environmental conditions that lead to the problem, and determine the efficacy of preharvest treatments with fungicides and water repellants (i.e., antitranspirant films and agricultural oils) in order to develop an effective management strategy.

\section{MATERIALS AND METHODS}

Fungal isolations from affected rind tissues. Symptomatic Satsuma mandarin (Citrus reticulata Blanco) fruit (cv. Frost Owari) were collected at two field sites in Butte County in the Sacramento Valley and one site in Fresno County in the San Joaquin Valley in 2002, 2003, and 2005 (a total of five samplings). Fungal isolations were conducted using standard procedures For this, lesions were surface sterilized for 1 min using sodium hypochlorite at 400 $\mathrm{mg} / \mathrm{liter}$, rinsed with sterile water, and plated onto potato dextrose agar (Difco Laboratories, Detroit, MI) amended with rifampicin at $20 \mathrm{mg} /$ liter (Sigma-Aldrich, St. Louis, MO) and 130 ampicillin at $\mathrm{mg} /$ liter (Sigma-Aldrich). Plates were incubated at $20^{\circ} \mathrm{C}$. Fungal isolates were identified based on cultural and microscopic characteristics.

Reproduction of rind disorder symptoms and evaluation of treatments to manage mandarin rind disorder in the laboratory. Mature Satsuma mandarin fruit (cv. Frost Owari) were submerged and incubated in distilled water at temperatures of $15,20,25$, or $30^{\circ} \mathrm{C}$ and were examined hourly for $6 \mathrm{~h}$ for the development of water-soaked lesions on the rind. Once lesions were observed, fruit were air dried and incubated for 3 days in closed plastic containers at $20^{\circ} \mathrm{C}$ and $\geq 95 \%$ relative humidity. Fruit were then evaluated for incidence and appearance of rind symptoms. Control fruit that did not receive the water treatment were stored for $6 \mathrm{~h}$ at $25^{\circ} \mathrm{C}$ and $35 \%$ relative humidity and were then also incubated for 3 days at $20^{\circ} \mathrm{C}$ and $\geq 95 \%$ relative humidity. Experiments consisted of three replications with eight fruit in each replication, and the experiment was done twice.

Satsuma mandarin fruit were dipped for $30 \mathrm{~s}$ in $2 \%(\mathrm{vol} / \mathrm{vol})$ summer spray oil 
(Omni Supreme Spray; Helena Chemical Company, Collierville, TN) containing $98 \%$ petroleum oil paraffin base or in $1 \%$ (vol/vol) of the agricultural antitranspirant di-1-p-menthene (VaporGard, Miller Chemicals, Hanover, PA). Control fruit were either dipped in distilled water or left untreated. After air drying at $24^{\circ} \mathrm{C}$ for 24 $\mathrm{h}$, fruit were submerged in distilled water for $10 \mathrm{~h}$ at $20^{\circ} \mathrm{C}$. Fruit were then air dried again and incubated for 3 days in closed plastic containers at $20^{\circ} \mathrm{C}$ and $\geq 95 \%$ relative humidity. Fruit were evaluated for incidence and severity of rind lesions. Experiments consisted of three replications with eight fruit in each replication, and the experiment was done twice.

Field trials on the evaluation of preharvest treatments for the management of mandarin rind disorder. Field trials were established in the fall of 2004 and 2005 on 8- to 10- and 18- to 20-year-old Satsuma mandarin (cv. Frost Owari) trees in groves in Butte and Fresno Counties, respectively, where mandarin rind disorder occurred in previous years. A randomized complete block design with four singletree replications was used for each treatment. Treatments were re-randomized in both plots each year. One to three applications of selected treatments were done between late-October and mid-November (Tables 1 to 4 ) starting 1 to 2 weeks after color break. All treatments were applied at a rate of 1,665 liters/ha using a backpack air-blast sprayer (Model SR420; Stihl Inc., Virginia Beach, VA). Treatments applied were an antitranspirant (VaporGard, 0.5\% $\mathrm{vol} / \mathrm{vol}$ ) and a summer oil (Omni Supreme Spray oil, $0.75 \%$ vol/vol), as well as the fungicides azoxystrobin (Abound 2F, 200 g/ha; Syngenta Crop Protection, Greensboro, NC) and the premixture pyraclostrobin-boscalid (Pristine 38WG, 920 g/ha; BASF Corp., Research Triangle Park, NC). In addition, in 2004 and 2005, one tree in an orchard in Butte County was protected from rain by a tent. Furthermore, in the Fresno County trials and in both years, control trees were compared with an adjacent row that was treated by the grower with gibberellic acid (ProGibb 40\%; Valent BioSciences Corp., Libertyville, IL) at 15 $\mathrm{mg} /$ liter approximately 2 weeks before color break (5 October 2004 and 6 October 2005). Trees were evaluated for the presence of rind disorder just before harvest between early and late December (or January for the gibberellic acid treatment) in each year. For this, 60 to 100 fruit on each tree around the perimeter of the tree and from each quadrant (15 to 25 fruit/ quadrant) were scored for the presence of dark-brown necrotic lesions, and incidence of mandarin rind disorder was based on the number of symptomatic fruit of the total number of fruit evaluated (percent incidence $=$ symptomatic/total fruit evaluated $\times 100$ ).

Environmental conditions and monitoring for mandarin rind disorder at field trial sites. For the experimental peri- ods of each year, data for precipitation and maximum and minimum temperatures were obtained from the California Irrigation Management Information System (http://wwwcimis.water.ca.gov). The Durham weather station was used for the Butte County site and the Orange Cove station was used for the Fresno County site. Both stations were within $25 \mathrm{~km}$ of their respective field sites. Data were summarized graphically. Monitoring for the initial occurrence of the disorder at each site and in each year was done 3 to 5 days following each rain event after fruit color break (midOctober to early November).

Statistical analysis of data. For repeated experiments in the laboratory, the homogeneity of variances was tested using

Table 2. Effect of preharvest field treatments for management of mandarin rind disorder (RD) in Butte County (Northern California), 2005

\begin{tabular}{llcccc}
\hline & & & \multicolumn{2}{c}{ Application dates } & \\
No. & \multicolumn{1}{c}{ Treatment $^{\mathbf{w}}$} & Product rates $^{\mathbf{x}}$ & $\mathbf{2 5}$ October & $\mathbf{1 5}$ November & RD $(\boldsymbol{\%})^{\mathbf{y}}$ \\
\hline 1 & Control & $\ldots$ & $\ldots$ & $\ldots$ & $59.6 \mathrm{a}$ \\
2 & Azoxystrobin & $200 \mathrm{~g} / \mathrm{ha}$ & $\ldots$ & $\ldots$ & $36.8 \mathrm{bc}$ \\
3 & Pyraclostrobin-boscalid & $920 \mathrm{~g} / \mathrm{ha}$ & $@$ & $\ldots$ & $52.0 \mathrm{ab}$ \\
4 & Spray oil & $0.75 \%(\mathrm{vol} / \mathrm{vol})$ & $@$ & $\ldots$ & $11.6 \mathrm{de}$ \\
5 & Spray oil & $0.75 \%(\mathrm{vol} / \mathrm{vol})$ & $@$ & $\ldots$ & $10.4 \mathrm{de}$ \\
6 & Di-1-p-menthene & $8.33 \mathrm{liter} / \mathrm{ha}$ & $@$ & $\ldots$ & $20.0 \mathrm{~d}$ \\
7 & Di-1-p-menthene & $8.33 \mathrm{liter} / \mathrm{ha}$ & $\ldots$ & $\ldots$ & $4.4 \mathrm{e}$ \\
8 & Protected $^{\mathbf{z}}$ & $\ldots$ & $\ldots$ & $\ldots$ & 0.0 \\
\hline
\end{tabular}

${ }^{\mathrm{w}}$ Randomized complete block design with four single-tree replications was used for each treatment.

${ }^{x}$ Products were applied on the dates indicated (@) using a backpack air-blast sprayer at a rate of 1,665 liter/ha.

y Evaluation was done on 2 December 2005 on 100 fruit for each tree.

${ }^{\mathrm{z}}$ One tree in the orchard was protected from rainfall by a tent. This treatment was not included in the statistical analysis.

Table 3. Effect of preharvest field treatments for management of mandarin rind disorder (RD) in Fresno County (Central California), 2004

\begin{tabular}{llcccc}
\hline & & & \multicolumn{2}{c}{ Application dates } & \\
No. & Treatment $^{\mathbf{x}}$ & Product rates $^{\mathbf{y}}$ & 21 October & $\mathbf{1 8}$ November & RD $(\%)^{\mathbf{z}}$ \\
\hline 1 & Control & $\ldots$ & $\ldots$ & $\ldots$ & $12.8 \mathrm{a}$ \\
2 & Azoxystrobin & $200 \mathrm{~g} / \mathrm{ha}$ & $\ldots$ & $\ldots$ & $1.0 \mathrm{~b}$ \\
3 & Di-1-p-menthene & $8.33 \mathrm{liter} / \mathrm{ha}$ & $\ldots$ & $\ldots$ & $0.0 \mathrm{~b}$ \\
4 & Di-1-p-menthene & $8.33 \mathrm{liter} / \mathrm{ha}$ & $\ldots$ & $\ldots$ & $0.7 \mathrm{~b}$ \\
5 & Spray oil & $0.75 \%(\mathrm{vol} / \mathrm{vol})$ & $\ldots$ & $\ldots$ & $1.0 \mathrm{~b}$ \\
6 & Spray oil & $0.75 \%(\mathrm{vol} / \mathrm{vol})$ & $@$ & $\ldots$ & $0.3 \mathrm{~b}$ \\
\hline
\end{tabular}

${ }^{\mathrm{x}}$ Randomized complete block design with four single-tree replications was used for each treatment.

y Products were applied on the dates indicated (@) using a backpack air-blast sprayer at a rate of 1,665 liter/ha.

${ }^{\mathrm{z}}$ Evaluation was done on 4 December 2004 on 60 fruit for each tree.

Table 1. Effect of preharvest field treatments for management of mandarin rind disorder (RD) in Butte County (Northern California), 2004

\begin{tabular}{|c|c|c|c|c|c|c|c|}
\hline \multirow[b]{2}{*}{ No. } & \multirow[b]{2}{*}{ Treatment $^{\mathrm{w}}$} & \multirow[b]{2}{*}{ Product rates $^{x}$} & \multicolumn{4}{|c|}{ Application dates } & \multirow[b]{2}{*}{$\mathbf{R D}(\%)$} \\
\hline & & & 22 October & 9 November & 19 November & 26 November & \\
\hline 1 & Control & $\ldots$ & $\ldots$ & $\ldots$ & $\ldots$ & $\ldots$ & $33.7 \mathrm{a}$ \\
\hline 2 & Azoxystrobin & $200 \mathrm{~g} / \mathrm{ha}$ & @ & $\ldots$ & @ & $\ldots$ & $31.3 \mathrm{a}$ \\
\hline 3 & Di-1-p-menthene & 8.33 liter/ha & @ & $\ldots$ & $\ldots$ & $\ldots$ & $4.0 \mathrm{~b}$ \\
\hline 4 & Di-1-p-menthene & 8.33 liter/ha & @ & @ & $\ldots$ & @ & $5.9 \mathrm{~b}$ \\
\hline 5 & Spray oil & $0.75 \%(\mathrm{vol} / \mathrm{vol})$ & @ & $\ldots$ & $\ldots$ & $\ldots$ & $2.0 \mathrm{~b}$ \\
\hline 6 & Spray oil & $0.75 \%(\mathrm{vol} / \mathrm{vol})$ & @ & @ & $\ldots$ & @ & $1.3 \mathrm{~b}$ \\
\hline 7 & Protected $^{\mathrm{z}}$ & $\ldots$ & $\ldots$ & & $\ldots$ & $\ldots$ & 0.0 \\
\hline
\end{tabular}

${ }^{\text {w }}$ Randomized complete block design with four single-tree replications was used for each treatment.

${ }^{x}$ Products were applied on the dates indicated (@) using a backpack air-blast sprayer at a rate of 1,665 liter/ha.

${ }^{\mathrm{y}}$ Evaluation was done on 3 December 2004 on 100 fruit for each tree.

${ }^{\mathrm{z}}$ One tree in the orchard was protected from rainfall by a tent. This treatment was not included in the statistical analysis. 
Bartlett's test of homogeneity. Variances were homogeneous and data were combined and further analyzed. For field trials, data for each site and year were analyzed separately. Incidence values for the disorder were arcsine transformed and data were analyzed using analysis of variance and least significant difference mean separation procedures (SAS version 9.1; SAS Institute Inc., Cary, NC).

\section{RESULTS}

Mandarin rind disorder symptoms and fungal isolations from affected rind tissues. Early and advanced symptoms of mandarin rind disorder are shown in Figure $1 \mathrm{~A}-\mathrm{C}$. Between 9 and 66 fungal isolates were obtained in each sampling of mandarin fruit with rind disorder in orchards in Butte and Fresno Counties over several years. Based on morphological identifications, fungal species most commonly isolated in the five samplings included Alternaria alternata (all samplings), Aureobasidium pullulans (two samplings), Cladosporium cladosporioides (three samplings), Epicoccum purpurescens (two samplings), Fusarium sp. (three samplings), Trichothecium roseum (two samplings), and Ulocladium botrytis (two samplings) (Fig. 2). Species of Macrophomina phaseolina and Melanconium sp. represented a major portion of isolates obtained in two of the samplings. Additional fungal species isolated were members of the genera Penicillium and Botrytis. Although species of Alternaria were obtained at every sampling, the frequency of isolation was inconsistent among orchards and years (Fig. 2).

Reproduction of rind disorder symptoms and evaluation of treatments to manage mandarin rind disorder in the laboratory. Symptoms of the rind disorder could be reproduced by soaking mature mandarin fruit in water at temperatures between 15 and $30^{\circ} \mathrm{C}$. Lesions first appeared after $4 \mathrm{~h}$ of incubation and more readily on fruit incubated at temperatures $\geq 20^{\circ} \mathrm{C}$. After $6 \mathrm{~h}$ when incubated at temperatures $\geq 20^{\circ} \mathrm{C}$, more than $80 \%$ of the fruit showed evidence of water soaking on parts of the rind surface. When fruit were subsequently air dried and then incubated at $20^{\circ} \mathrm{C}$ for 3 days, rind disorder symptoms developed with an appearance similar to those observed in the field (Fig. 1D). Significant $(P<0.05)$ differences in the incidence of rind lesions occurred between water temperatures used for soaking fruit. Approximately $60 \%$ of the fruit that were soaked in water at $\geq 20^{\circ} \mathrm{C}$ showed symptoms, whereas the incidence was approximately $30 \%$ for fruit soaked at $15^{\circ} \mathrm{C}$. Control fruit not soaked in water and incubated under conditions similar to the soaked fruit did not develop symptoms.

When fruit were treated with agricultural spray oil or an antitranspirant prior to soaking in water, the incidence of rind lesion development was significantly $(P<$ $0.05)$ lower than in untreated fruit. For the two tests conducted, an average of $86.1 \%$ of the control fruit exhibited the rind disorder whereas, for the spray oil and antitranspirant treatments, the incidence was 36.1 and $58.3 \%$, respectively.

Evaluation of preharvest treatments for the management of mandarin rind disorder in the field. Field trials were conducted at locations in northern and central California in 2004 and 2005 and results are shown in Tables 1 to 4 . Rind disorder developed in all trials. The incidence of the disorder on nontreated control trees varied among locations and years. In the Butte County trials, it was 33.7 and $59.6 \%$ and, in the Fresno County trials, it was 12.8 and $16.8 \%$ for 2004 and 2005, respectively. In all trials, treatments with the antitranspirant di-1-p-menthene or agricultural spray oil were consistently highly effective and significantly $(P<$ $0.05)$ reduced the incidence of the disorder from that of the control. In three of the four trials using these treatments, there was no significant difference in efficacy between a single-spray program with an application in late October and programs that included one (Tables 2 to 4) or two (Table 1) subsequent treatments. In one trial, two applications with the antitranspirant were significantly $(P<$ $0.05)$ more effective than a single application (Table 2). When single trees within an orchard were protected from rain by

Table 4. Effect of preharvest field treatments for management of mandarin rind disorder (RD) in Fresno County (Central California), 2005

\begin{tabular}{|c|c|c|c|c|c|}
\hline \multirow[b]{2}{*}{ No. } & \multirow[b]{2}{*}{ Treatment $^{\mathrm{x}}$} & \multirow[b]{2}{*}{ Product rates $^{\mathrm{y}}$} & \multicolumn{2}{|c|}{ Application dates } & \multirow[b]{2}{*}{$\mathbf{R D}(\%)^{\mathrm{z}}$} \\
\hline & & & 20 October & 22 November & \\
\hline 1 & Control & & $\ldots$ & $\ldots$ & $16.8 \mathrm{a}$ \\
\hline 2 & Azoxystrobin & $200 \mathrm{~g} / \mathrm{ha}$ & @ & @ & $5.7 \mathrm{bc}$ \\
\hline 3 & Pyraclostrobin-boscalid & $920 \mathrm{~g} / \mathrm{ha}$ & @ & @ & $8.4 \mathrm{ab}$ \\
\hline 4 & Spray oil & $0.75 \%(\mathrm{vol} / \mathrm{vol})$ & @ & $\ldots$ & $4.8 \mathrm{bc}$ \\
\hline 5 & Spray oil & $0.75 \%(\mathrm{vol} / \mathrm{vol})$ & @ & @ & $0.8 \mathrm{c}$ \\
\hline 6 & Di-1-p-menthene & 8.33 liter $/ \mathrm{ha}$ & @ & $\ldots$ & $3.6 \mathrm{c}$ \\
\hline 7 & Di-1-p-menthene & 8.33 liter/ha & @ & @ & $3.6 \mathrm{c}$ \\
\hline
\end{tabular}

${ }^{\mathrm{x}}$ Randomized complete block design with four single-tree replications was used for each treatment.

y Products were applied on the dates indicated (@) using a backpack air-blast sprayer at a rate of 1,665 liter/ha.

${ }^{\mathrm{z}}$ Evaluation was done on 6 December 2005 on 60 fruit for each tree.

tenting, the disorder did not develop (Tables 1 and 2).

Gibberellic acid treatments, applied approximately 2 weeks before the color
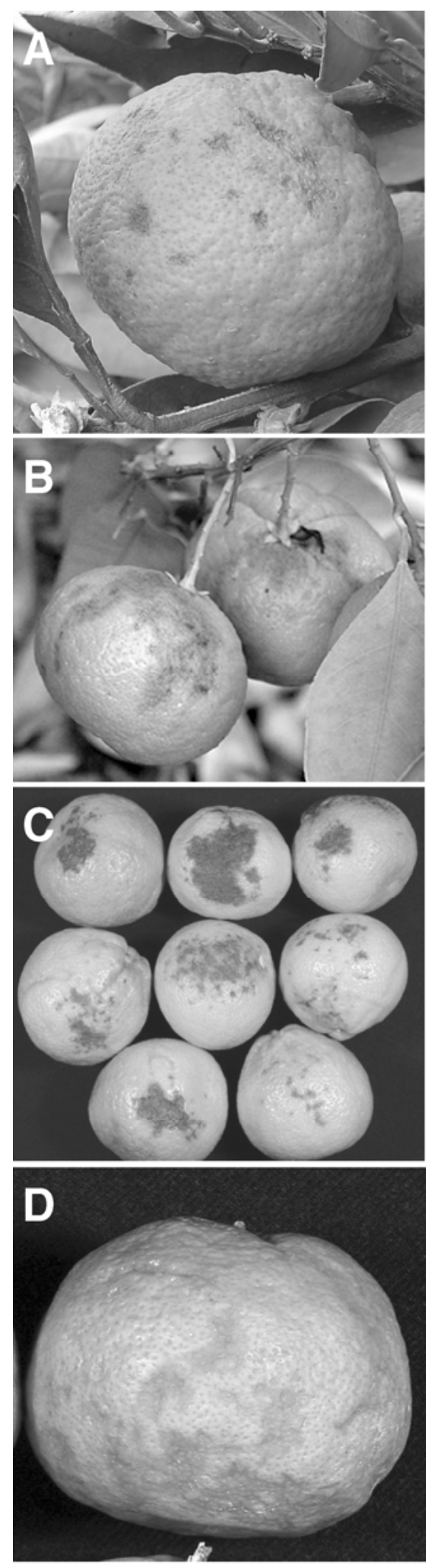

Fig. 1. Symptoms of mandarin rind disorder naturally occurring in the field or reproduced in the laboratory. A, Early and B, advanced symptoms; and $\mathbf{C}$, a range of symptoms on fruit from the field. D, Symptoms on a fruit that was soaked in the laboratory for $6 \mathrm{~h}$ in water at $20^{\circ} \mathrm{C}$, air dried, and incubated at $20^{\circ} \mathrm{C}$ for 3 days. 
break stage of fruit development, were also highly effective, reducing mandarin rind disorder from an average of $12.8 \%$ incidence in the control to $1.8 \%$ in the gibberellic acid treatment. The harvest date of the gibberellic-acid-treated fruit was delayed approximately 1 to 1.5 months in each year of the study.

The effect of fungicide treatments (i.e., azoxystrobin or pyraclostrobin-boscalid) on the incidence of rind disorder was inconsistent between the trial sites and years. Pyraclostrobin-boscalid was ineffective at the Butte County site (Table 2) and numerically but not statistically reduced the disorder at the Fresno County site (Table 4). Azoxystrobin, used in all four field tests, was ineffective in one of the Butte County trials (Table 1) but, in the second one, significantly $(P<0.05)$ reduced the incidence of the disorder to $36.8 \%$ compared with $59.6 \%$ in the control (Table 2). In both of the Fresno County trials, azoxystrobin showed an efficacy similar to the oil and antitranspirant treatments (Tables 3 and 4).

Environmental conditions and monitoring for mandarin rind disorder at field trial sites. Environmental conditions at the trial sites were summarized for the experimental period (20 October to 6 December) for each year (Fig. 3A-D). No rainfall occurred prior to 17 October and total precipitation was 116.5 and $78.7 \mathrm{~mm}$ for the Butte County site, whereas it was 50.0 and $18.3 \mathrm{~mm}$ for the Fresno County site in 2004 and 2005, respectively. Average temperatures ranged from 2.9 to $14.3^{\circ} \mathrm{C}$ and 3.2 to $15.7^{\circ} \mathrm{C}$ for the Butte County site and from 2.9 to $14.6^{\circ} \mathrm{C}$ and from 4.4 to $19.1^{\circ} \mathrm{C}$ for the Fresno County site in 2004 and 2005, respectively. Daily shifts and differences in temperature lows and highs during the period of color break of the fruit rind at both locations were more severe in 2005 than in 2004 (Fig. $3 \mathrm{~A}-\mathrm{D})$. Disease symptoms developed in the field within 3 to 5 days after rain associated with a sudden drop in temperature had occurred each fall season between late October and early November (Fig. 3A-D).

\section{DISCUSSION}

Mandarin rind disorder has become of increasing concern in recent years in California. The popularity of early season mandarin fruit cultivars (e.g., Satsuma and Clementine) has led to an increase in acreage, including in areas where environmental conditions are not considered optimal for growing this crop, such as the northern areas of the state where high rainfall is common in early to midwinter. In this study, we elucidated the cause of a rind disorder of mandarin fruit in California and, for the first time, we developed an effective and economic management strategy that may also be valuable for use on other citrus species where similar damage has been reported $(1,2)$. As in previous studies done on orange by Fawcett (10), we were able to reproduce rind disorder symptoms by soaking fruit in water at a range of temperatures between 15 and $35^{\circ} \mathrm{C}$. Symptoms on mandarin fruit developed after 4 to $6 \mathrm{~h}$ of water treatment in our studies, whereas 15 to $36 \mathrm{~h}$ were required for orange (10). Symptoms probably developed after shorter water-exposure durations on mandarin fruit because rind tissue is thinner and more delicate than that of orange fruit. Water damage to orange fruit has been attributed to small injuries in the rind where water is more easily imbibed (10).

Rind disorder developed in all four of our field trials. In both years of the study, incidence of the disorder and precipitation
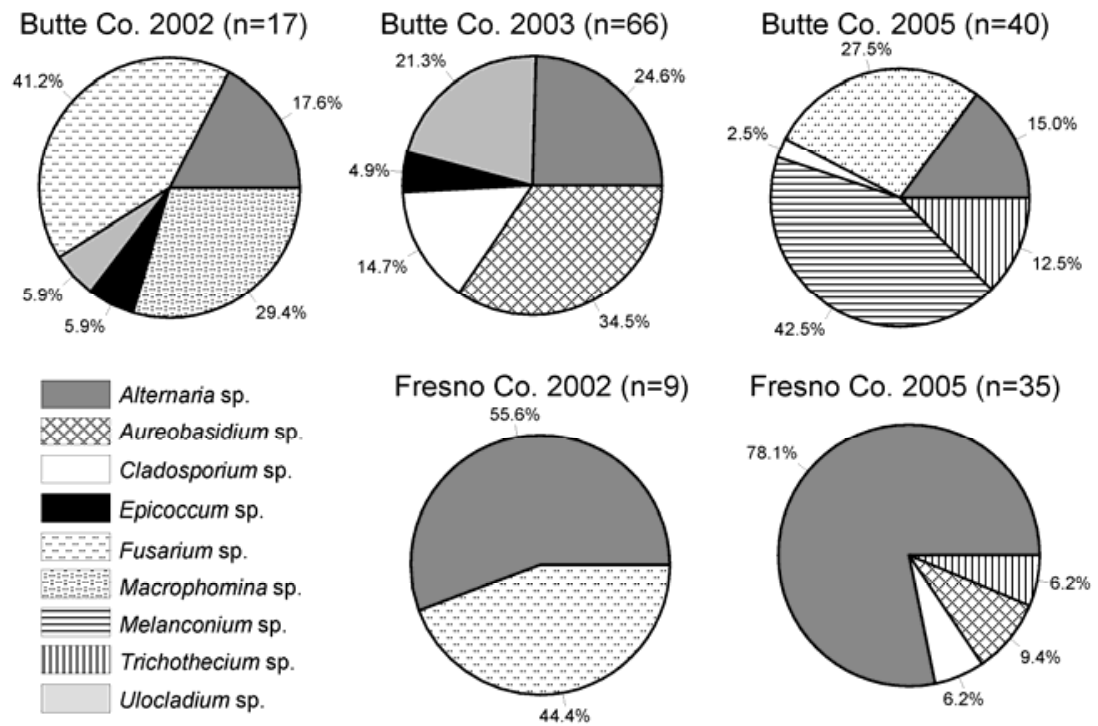

Fig. 2. Incidence of fungi isolated from mandarin rind tissue showing symptoms of the disorder. Isolations were done from two field sites in Butte County, one in 2002 and the other one in 2003 and 2005, whereas isolations in Fresno County were done from one orchard in 2002 and 2005. Number of fungal isolates $(n)$ obtained in each sampling are shown in parentheses. were higher at the Butte County site in northern California compared with the Fresno County site in central California. At both locations, however, the incidence of the disorder was lower in the highprecipitation season 2004 than in 2005, when less rainfall occurred. Thus, there was no consistent correlation between the amount of rainfall and the incidence of rind disorder. Trees protected from rainfall did not develop rind disorder, whereas neighboring, unprotected trees showed a high incidence of damaged fruit. This strongly indicates that wetness is involved in causing rind injury. Other environmental factors, however, likely contribute to the development of the disorder. Fawcett (10) observed that a rind breakdown of orange fruit was more severe in orchard locations with greater temperature shifts. A severe preharvest rind-spotting of Clementine mandarin in Greece, that first developed at the stylar end of the fruit at color break and was first thought to be caused by nutritional imbalances, was also attributed to environmental conditions (3). The authors of the latter study observed that initial symptom development coincided with days of low temperature and high relative humidity following a period of high temperature, low relative humidity, and high evapotranspiration. Environmental data for our two trial sites indicated differences in temperature fluctuations between the 2 years of the study. Differences in minimum and maximum temperature values during the period of color break of the fruit rind were greater in 2005 than in 2004. Thus, this likely exacerbated the severity of the disorder in the 2005 season.

In our isolations from affected rind tissue, species from numerous fungal genera were recovered. These fungi are recognized as commonly occurring epiphytic fungi that inhabit the fruit surface and are known to be associated with windborne soil deposits on plant tissue. Most are considered opportunistic secondary colonizers of injured tissues; however, Alternaria spp. are also known as citrus fruit pathogens. There was no consistent association of the isolated fungi among samplings and locations. In addition, treatments with the broad-spectrum fungicides azoxystrobin or pyraclostrobin-boscalid were inconsistent in their efficacy. Thus, there was no evidence for a primary role of these fungi in causing the rind disorder.

Oil gland disruption and subsequent tissue injury that have been associated with oleocellosis of citrus fruit $(16,17)$ were not found in microscopic observations on rindspotting of Clementine mandarin in Greece; however, microscopic cracks were located in the spotted areas (3). Although not investigated in our study, cracks like these could represent entryways of various fungal organisms that are not primary pathogens. In the absence of oil gland injury, rind damage of citrus fruit has been 
associated with plasma membrane collapse and release of cytotoxic d-limonene, essential oils, or other lipids from their subcellular compartments into the cell lumen $(1,13,14)$.

Management strategies that we developed in this study were based on the prevention of water saturation of the fruit rind, and this was successfully achieved by the application of an agricultural summer oil (8) or an antitranspirant (7). These products form a fine film on the fruit surface that acts as a water-repellant. The high and consistent efficacy of these treatments in our field studies supports our conclusion that the described rind breakdown of fruit that has undergone a color change from green to orange is a physiological, waterassociated disorder rather than a pathological problem caused by fungi or other organisms. In our studies, a single application was sufficient to protect fruit until harvest; therefore, treatments were persistent for at least 1 month. However, in highrainfall years, a second application may be beneficial. Treatments with oil or an antitranspirant were less effective in our laboratory tests when compared with the field trials, possibly because fruit in the laboratory were subjected to more extensive water soaking.

Field treatments with gibberellic acid also reduced the incidence of the rind disorder to very low levels compared with the control fruit. Gibberellic acid delays fruit ripening (9) and, apparently, the immature fruit rind is less prone to environmentally caused damage during the late-fall climatic conditions in California. Coggins and Eaks (5) also reported reduced susceptibility of
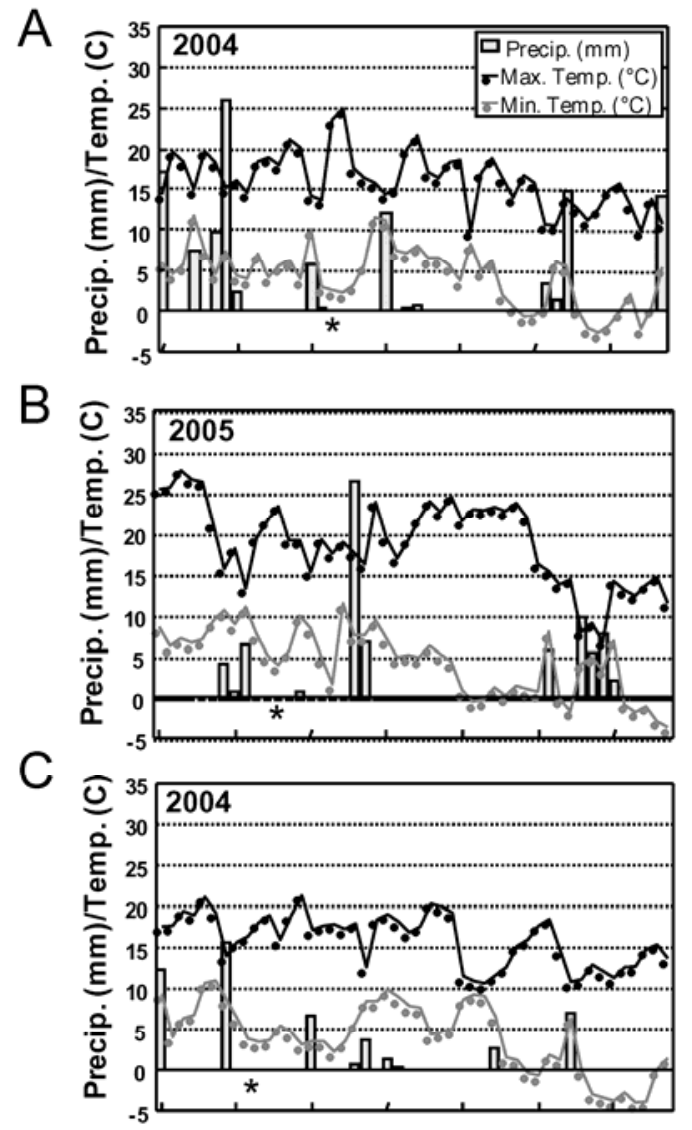

$\mathrm{D}$

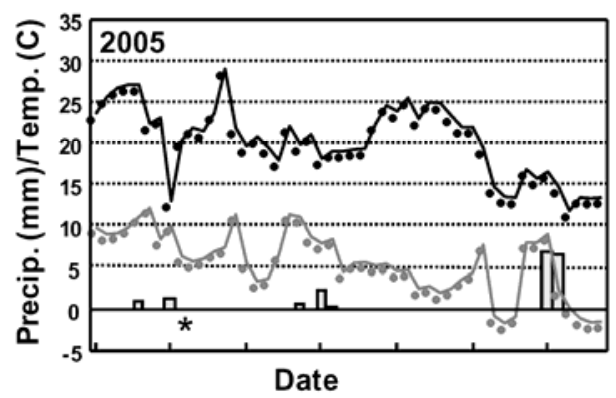

Fig. 3. Precipitation and maximum/minimum temperature from two orchard sites in California: Butte County site in A, 2004 and B, 2005, respectively; and Fresno County site in C, 2004 and D, 2005, respectively. Data were obtained from the California Irrigation Management Information System from 19 October to 15 December for each year. A-D, Asterisk in each figure indicates the date when symptoms of mandarin rind disorder were first observed in the field.
Navel orange to rind damage after sprays with gibberellic acid in California. In our studies, the incidence of the disorder on the gibberellic-acid-treated fruit was still low $(<3 \%)$ at harvest time in January although additional rainfall occurred during fruit ripening. Possibly, the less extreme temperature fluctuations during the winter season (compared with the fall season) reduced the impact of water damage. Although gibberellic acid could be another effective treatment for management of the rind disorder, the high demand of mandarin fruit during the December holiday season and potential overlapping harvest dates with other mandarin cultivars (because of a delayed harvest of early-season Satsuma fruit) will not make it an economic option. For Navel orange, extending the irrigation intervals before the winter months was suggested to allow fruit to become cold resistant and less prone to weatherassociated rind damage (11). This strategy has not been investigated for mandarin. Mandarin growers, however, are reluctant to reduce water applications in the fruitripening stages prior to harvest in an effort to minimize water stress of trees.

Although fungal organisms were not considered a cause of the mandarin rind disorder described in this study, fungicides significantly reduced the incidence of the disorder in some of the trials, especially at the Fresno County site where the amount of rainfall was lower. This partial efficacy could possibly be due to growth regulator effects of fungicides such as the QoI compounds (18). Additionally, fungicides may prevent the secondary colonization of fungal organisms and, thus, reduce spoilage of harvested fruit. Still, although some benefits may be obtained with the use of broadspectrum fungicides, the emphasis in management should be on preventing water saturation of fruit and injury during the final period of fruit maturation. However, it has to be considered, that, in other geographical locations and under different environments, rind disorders of citrus fruit that are similar in appearance may have other primary causes such as chilling $(10,15)$. In some cases, the cause of the rind disorder remained unknown $(2,15)$.

To manage the water-associated rind disorder of mandarin fruit, the use of water-repellent treatments prior to fall rains at or just before fruit color break has now been successfully adapted by the California mandarin industry. This strategy fulfills market needs without causing delays in harvest that generally result when treating fruit with gibberellic acid, and does not compromise other orchard practices such as irrigation schedules that may affect fruit quality.

\section{ACKNOWLEDGMENTS}

We thank M. Freeman (University of California, Cooperative Extension, Fresno County), G. Driever, and D. F. Thompson for assisting in field trials with the application of treatments, monitoring for the 
disorder, and in evaluations of the performance of treatments; and the growers (R. Lynn, L. Lodigiani, and S. Jorgenson) who cooperated in these studies and allowed us to conduct trials in their mandarin groves.

\section{LITERATURE CITED}

1. Agusti, M., Almela, V., Juan, M., Alferez, F., Tadeo, F .R., and Zacarias, L. 2001. Histological and physiological characterization of rind breakdown of 'Navelate' sweet orange. Ann. Bot. 88:415-422.

2. Arpaia, M. L., Kahn, T. L., El-Otmani, M., Coggins, C. W., Jr., DeMason, D. A., O'Connell, N. V., and Pehrson, J. E., Jr. 1991. Pre-harvest rindstain of 'Valencia' orange: histochemical and developmental characterization. Sci. Hortic. 46:261-274.

3. Assimakopoulou, A., Tsougrianis, C., Elena, K., Fasseas, C., Karabourniotis, G. 2009. Preharvest rind-spotting in 'Clementine' mandarin. J. Plant Nutr. 32:1486-1497.

4. Chapman, H. D. 1958. The citrus industry of South Africa. Calif. Citrogr. 43:179-181.

5. Coggins, C. W., and Eaks, I. L. 1964. Rind staining and other rind disorders of navel orange reduced by gibberellin. Calif. Citrogr. 50:47.
6. Connell, J., Forster, H., Driever, G., Thompson, D. F., and Adaskaveg, J. E. 2006. Etiology and management of rind breakdown of mandarins. (Abstr.) Phytopathology 96:S26.

7. Davenport, D .C., Hagan, R. M., and Martin, P. E. 1969. Antitranspirants...uses and effects on plant life. Calif. Turfgrass Cult. 19:25-27.

8. Davidson, N. A., Dibble, J. E., Flint, M. L. Marer, P. J., and Guye, A. 1991. Managing insects and mites with spray oils. Univ. Calif. Div. Agric. Nat. Resour. Publ. 3347. Oakland.

9. El-Otmani, M., Coggins, C. W., Agusti, M., and Lovatt, C. J. 2000. Plant growth regulators in citriculture: world current uses. Crit. Rev. Plant Sci. 19:395-448.

10. Fawcett, H.S. 1936. Citrus Diseases and Their Control. McGraw-Hill Book Company, Inc., New York.

11. Klotz, L. 1978. Fungal, bacterial, and nonparasitic diseases and injuries originating in the seedbed, nursery, and orchard. Pages 1-66 in: The Citrus Industry. Vol. IV. Eds. W. Reuther, E. C. Calavan, and G. E. Carman. Div. Agric. Sci. Nat. Resour. Publ. No. 4088. University of California, Oakland.

12. Klotz, L. J., Coggins, C. W., and DeWolfe, T. A. 1966. Rind breakdown of navel oranges.
Calif. Citrogr. 51:174-196.

13. Medeira, M. C., Maia, M. I., and Vitor, R. F 1999. The first stages of pre-harvest 'peel pitting' development in 'Encore' mandarin. An histological and ultrastructural study. Ann Bot. 83:667-673.

14. Obenland, D. M., Margosan, D. A., and Houck, L. G. A. 1997. Essential oils and chilling injury in lemon. HortScience 32:108-111.

15. Porat, R., Weiss, B., Cohen, L., Daus, A., and Aharoni, N. 2004. Reduction of postharvest rind disorders in citrus fruit by modified atmosphere packaging. Postharvest Biol. Technol. 33:35-43.

16. Sawamura, M., Manabe, T., Oonishi, S Yauoka, K., and Kusunose, H. 1984. Effects of rind oils and their components on the induction of rind spot in citrus species. J. Hortic. Sci. 59:575-579.

17. Shomer, I., and Erner, Y. 1989. The nature of oleocellosis in citrus fruits. Bot. Gaz. 150:281 288.

18. Wu, Y.-X., and von Tiedemann, A. 2001 Physiological effects of azoxystrobin and epoxiconazole on senescence and the oxidative status of wheat. Pestic. Biochem. Physiol. 71:1-10. 